\title{
Dyspnoea in a 72-year-old woman
}

\author{
Alessandra Guido, ${ }^{1}$ Lorenzo Fuccio, ${ }^{2}$ Lucia Giaccherini, ${ }^{1}$ Alessio Giuseppe Morganti ${ }^{1}$
}

${ }^{1}$ Division of Radiation Oncology, S Orsola-Malpighi Hospital, University of Bologna, Bologna, Italy

${ }^{2}$ Department of Medical and Surgical Sciences (DIMEC), Alma Mater StudiorumUniversity of Bologna, S Orsola-Malpighi Hospital, University of Bologna, Bologna, Italy

\section{Correspondence to} Dr Lorenzo Fuccio, lorenzofuccio@gmail.com

Accepted 8 October 2015
CrossMark

To cite: Guido A, Fuccio L, Giaccherini L, et al. BMJ

Case Rep Published online: [please include Day Month Year] doi:10.1136/bcr-2015212897

\section{DESCRIPTION}

A 72-year-old woman presented to our hospital, with progressive shortness of breath and dry cough for 3 months. She denied fever and had no symptoms of cardiopulmonary involvement. She had a history of hypertension. In 2009, the patient had a sigmoid colon carcinoma with synchronous single liver metastasis; both lesions were surgically treated followed by chemotherapy. In 2011, a diagnosis of metachronous solitary lung metastasis was made and a lobectomy performed.

On admission, the patient's chest CT was negative for lesions and laboratory analyses were unremarkable (normal serum level of carcinoembryonic antigen). Fluorodeoxyglucose positron emission tomography/CT revealed a focal uptake of a lesion in the larynx, at the cricoid cartilage level (diameter $11 \times 4 \mathrm{~mm}$; $\quad$ SUVmax $=22$ ) (figures 1 and 2). Endoscopic evaluation of the larynx showed a protruding $10 \mathrm{~mm}$ mass at the glottic level causing more than half reduction of the airway. The lesion was sampled and a diagnosis of moderately differentiated adenocarcinoma (CDX2+; $\mathrm{CK} 20+$, TTF-1-), suggestive of metastasis from colon cancer, was made. Palliative radiotherapy treatment was administered (30 Gy in 10 fractions). After 6 months, at the end of treatment, the patient was alive, without evidence of recurrence.

Laryngeal metastases are infrequent events, mainly originating from melanoma and kidney tumours, ${ }^{1}$ and few cases of colon metastasis have been reported. ${ }^{2} 3$ The standard of treatment for these cases includes both endoscopic and radiotherapeutic approaches. Direct laryngoscopy with laser treatment and debulking of the laryngeal obstructing mass have been proposed. Radiotherapy may represent a valid alternative, allowing prolonged palliation.

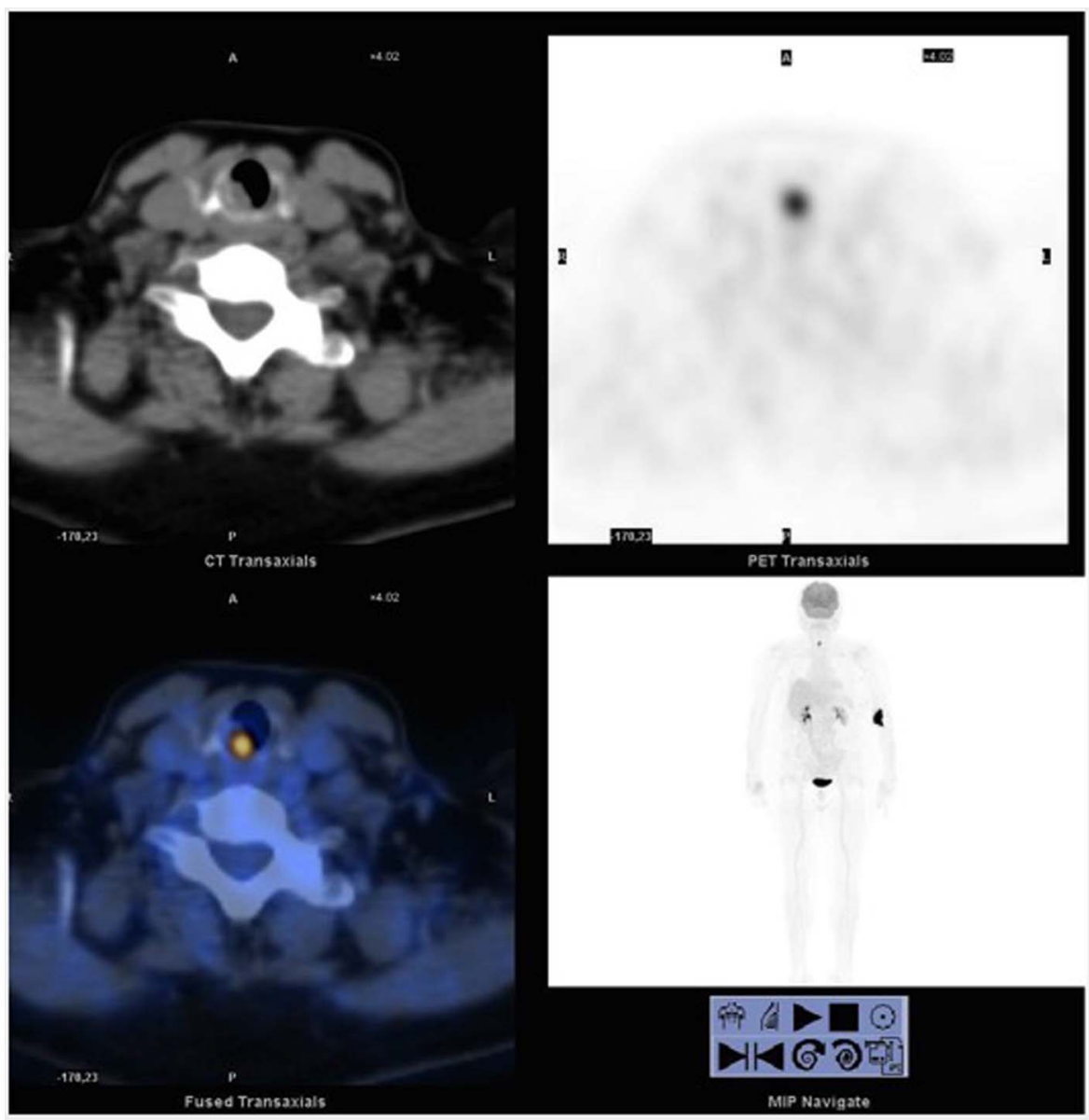

Figure 1 Positron emission tomography/CT axial view revealing focal uptake of a $1.1 \mathrm{~cm}$ lesion in the larynx, at the cricoid cartilage level (SUVmax=22). 
Figure 2 Positron emission tomography/CT sagittal view of an obstructing lesion at the larynx.

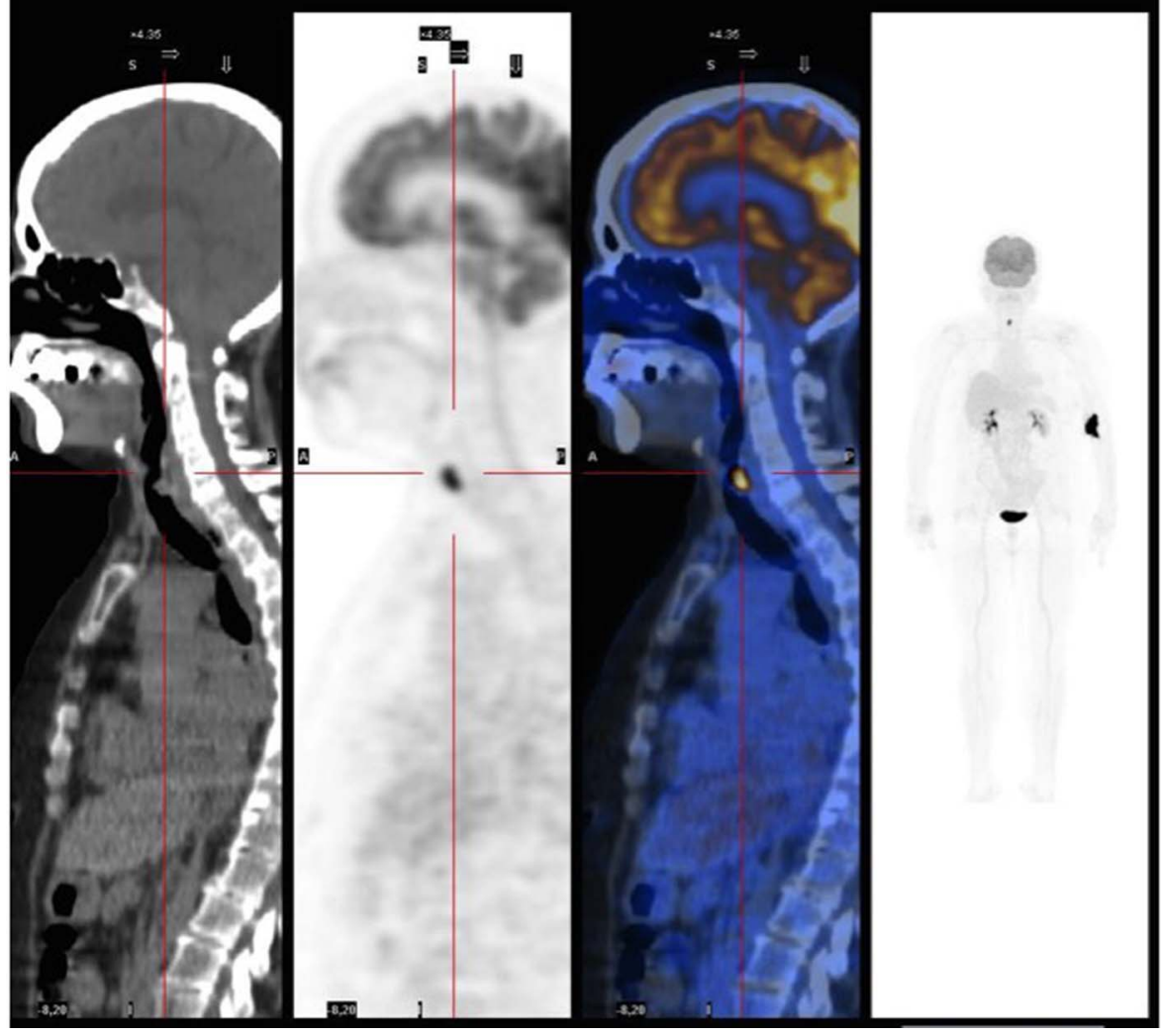

Competing interests None declared.

Patient consent Obtained.

Provenance and peer review Not commissioned; externally peer reviewed.

\section{REFERENCES}

1 Ferlito A. Secondary neoplasms. In: Ferlito A. ed. Neoplasms of the larynx. Edinburgh: Churchill Livingstone, 1993:349-60.

2 Marioni G, De Filippis C, Ottaviano G, et al. Laryngeal metastasis from sigmoid colon adenocarcinoma followed by peristomal recurrence. Acta Otolaryngol 2006;126:661-3.

3 Terashima S, Watanabe $S$, Shoji M. Long-term survival after resection of metastases in the lungs and larynx originating from sigmoid colon cancer: report of a case. Fukushima J Med Sci 2014;60:82-5.

the data acquisition. AG and $L F$ contributed to drafting the manuscript. LG and AGM contributed to critical revision. AGM gave the final approval.

Copyright 2015 BMJ Publishing Group. All rights reserved. For permission to reuse any of this content visit http://group.bmj.com/group/rights-licensing/permissions.

BMJ Case Report Fellows may re-use this article for personal use and teaching without any further permission.

Become a Fellow of BMJ Case Reports today and you can:

- Submit as many cases as you like

- Enjoy fast sympathetic peer review and rapid publication of accepted articles

- Access all the published articles

- Re-use any of the published material for personal use and teaching without further permission

For information on Institutional Fellowships contact consortiasales@bmjgroup.com

Visit casereports.bmj.com for more articles like this and to become a Fellow 